\title{
¿Qué escriben y cómo escriben las mujeres?
}

\author{
María Teresa Andruetto ${ }^{\circ}$
}

No sé si podría generalizar. Hay tantas mujeres como escrituras, por lo tanto intentaré hablar de lo que escribo yo, esta mujer que soy.

Me interesa la intensidad. Esa verdad de otro que en el proceso de escritura tal vez podemos captar, por eso siempre fui hacia escenas con las que sentí empatía porque he podido percibir algo que me unía a ese otro. El gran aprendizaje es cómo ser un observador intenso y no un espectador. Me doy cuenta en seguida cuando el camino para encontrarse con eso no ha sido verdadero.

Me interesa generar espacios para expandir los modos de pensar y de sentir, eso es lo más político del asunto: estrategias para poner en cuestión nuestras certezas. Lo que une al arte con la política es la posibilidad de establecer disenso, cómo me salgo de mí para mirar desde otro, porque tal vez las cosas no son como yo pensaba que eran. Tengo posicionamiento sobre muchos asuntos, cualquiera lo puede percibir, sin embargo nunca he tenido ni querido una escritura militante. A la hora de escribir, busco las zonas sutiles, los grises, los bordes, las incertezas, lo incómodo. Así como estuvo siempre mi interés por lo social y lo político, también estuvo siempre la riqueza de la palabra.

El narrador y su punto de vista son para mí más importante que los personajes. En la escritura no hay una sola verdad. La vida es así, inestable. Una novela, un cuento, son una voz que susurra al oído. Los escritores escribimos con un material prestado, porque la lengua no es nuestra, es de todos y fue construida por todos. En la oralidad está el lugar más vital de una lengua, también el más inestable, más inseguro, más inapresable. Cómo volver verdadera una voz, ese es el desafío. Ese personaje, que está hecho sólo de palabras, en su modo de decir, habla de sí mismo. Estoy muy atenta a los registros del habla, a los matices que eso tiene, porque en los matices está todo: convicciones, contradicciones, conocimiento y confusión. Un escritor no es un guardián de la lengua, sino alguien capaz de captar los pequeños desvíos que en el habla de alguien se producen.

\footnotetext{
- Escritora, nació en $A^{\circ}$ Cabral en 1954. Publicó libros de poemas, novelas, cuentos, ensayos y libros para niños y jóvenes lectores. Su obra fue traducida a varias lenguas. Obtuvo, entre otros, el Premio Novela del Fondo Nacional de las Artes 2002, fue finalista del certámen Rómulo Gallegos en 2010, ganó el Premio Trayectoria en Literatura Infantil SM (Guadalajara, 2009), el Premio Cultura de la Universidad Nacional de Córdoba y el Premio Hans Christian Andersen en 2012 y el Konex de Platino en 2014.
} 
La literatura es memoria, no solo memoria histórica, sino también memoria del cuerpo, memoria de la vida cotidiana, memoria relatada por las mujeres de la casa. No hay una sola memoria y la memoria de cada quien está llena de olvido. Marc Augé dice que si no existiera el olvido, no existirían memorias, la memoria siempre opera por selección y esa selección no es gratuita en el sentido de que también es ideológica. Esas memorias son como un río subterráneo que en algunas circunstancias irrumpe y sale a la superficie, luego vuelve a hundirse y va y viene, pero que siempre está en nosotros. Es verdad que hay ciertos sectores populares que han perdido la memoria y ese es uno de los grandes dolores que tengo en este momento, pero también es cierto que hay un saber que está en el cuerpo y que rebrota. Esa voz social tarde o temprano regresa, del mismo modo en que en los procesos individuales regresa lo reprimido una y otra vez hasta que se hace un lugar en lo consciente. Las formas del arte que más me interesan son las que nos conectan con esa zona subterránea. Un individuo que yendo hacia sí mismo logra extraer algo de la voz social que fue macerando en él. Por eso, en los mejores momentos de los mejores escritores, quien habla por ellos es una sociedad.

Autobiografía/fabulación. Mis libros parecen más autobiográficos de lo que son, creo que eso tiene que ver con el modo de trabajo. Entra lo biográfico porque es casi imposible que no entre en una ficción, pero a la vez cuando uno intenta ser fiel a lo biográfico es difícil escapar a la fabulación. Yo no creo que haya una trasposición, creo en la escritura. Creo en el trabajo de cocción que la escritura hace con la vida. La ficción es el paso de lo crudo a lo cocido; hay una materia cruda que es la vida, que no está toda junta. En ese proceso de cocción el narrador lo es todo, hasta que no tenga un narrador que delimite qué entra y qué no (porque es tan importante lo que ingresa como lo que queda afuera) eso que tengo no entra en ebullición, no leuda. El escritor es como un cocinero, la escritura es cocción de ingredientes muy diversos; la gracia está en que la cocción se haga de tal manera que no se noten los ingredientes.

La identidad atraviesa de diversas maneras todas las cosas que he escrito, tal vez porque soy hija y nieta de inmigrantes que perdieron su lugar y aquí se buscaron a ellos mismos. Algo de esa nostalgia heredada que me circundaba le dio un tono a mi relación con el mundo. En los pueblos de donde provengo, la gente añoraba algo ilusorio también. Se dice que la escritura nace de la falta, que cuando no está la cosa, aparece la palabra. Yo me alimenté de dos faltas porque había muchos relatos de mi padre del mundo de allá, que era un mundo muy presente, pero virtual a la vez. Y también había una falta en mi madre porque tenía un universo interior muy rico, le gustaba leer y escribía unas cartas preciosas y en eso estaba el sueño de una cosa mayor que nunca se concretó, porque ella se crió en un pueblo donde había sólo escuela primaria. Esas faltas se unieron en ese deseo mío y entonces la búsqueda ha ido por ahí, por ese lugar de identidad que es mío y es a la vez social porque desde mi paso por la universidad, que fueron años de mucho compromiso político, yo empecé a leer en contexto y nunca más leí nada sin una dialéctica con el medio y con la tradición de la lengua. 


\section{¿Cuál es el lugar que ocupa la literatura escrita por mujeres en el canon y en las decisiones de quienes diseñan los espacios curriculares?}

Tradición/genealogía. Hay cambios en esto, hay ciertas convicciones en las mujeres que hacen que insistamos en posicionar escrituras de mujeres, hay proliferación de estudios académicos. La maternidad me atraviesa en mi condición de madre y en mi condición de hija y más allá también a mis abuelas y a otras mujeres reales que entraron a alimentar mi imaginario con sus relatos. La colección Narradoras argentinas, que hacemos con Juana Luján y Carolina Rossi en el marco de la editorial universitaria EDUVIM, es un modo de mirar a las madres literarias. Hay algo del traspaso generacional, entre mujeres, que me atraviesa. Algo de este espíritu está en esta colección. Rastreamos escritoras, leemos o releemos escrituras, buscamos hacia atrás en las mujeres que escribieron y publicaron, para aprender de ellas, valorarlas, en el deseo de armar una genealogía, con la convicción de que nadie se hace solo.

\section{Acerca de la escritura}

Todo comienza con ciertos relámpagos de vida de otros que me llaman la atención porque en algún punto, todavía desconocido, se vinculan con algo muy propio. Después viene un arduo acto de magia: lograr que lo que veo se vuelva visible para otros. Lo que me atrae: escenas que presentan un ligero desacomodo/ disfunción/corrimiento de lo habitual, o que contradicen algún preconcepto que hasta entonces yo tenía sobre ciertas cuestiones. No me interesa lo que escandaliza ni tampoco lo verdaderamente extraordinario, me atrae más lo que es apenas un poco extraño, lo que se esconde bajo las apariencias, lo extraordinario o lo oscuro que habita en la vida de todos y que sólo con mucha atención, a veces, se deja ver. El huevo es el descubrimiento involuntario de una escena, después voy cavando ahí hasta que algo que todavía no conozco se revela en un sentido casi fotográfico.

Hay una frase de Demócrito de Abdera que siempre recuerdo: «todo está hecho de azar y necesidad", porque si bien el comienzo es azaroso, luego lo que me guía y empecina es la sospecha de que ahí se esconde una verdad personal. En ese alambique se fusionan experiencia e imaginación, lo ficcional y la (propia) vida.

Nunca escribí historias reales, pero tampoco puramente imaginadas. Todo lo que hice condensa situaciones que vi o escuché en oportunidades y tiempos diversos y también hay mucho autobiográfico que se filtra, pero nunca como un propósito sino de un modo que llamaría estallado (como si se rompiera un vaso en miles de pequeñísimos fragmentos y esos fragmentos se desparramaran en el texto y ya no pudiera quitarlos y a veces ni siquiera reconocerlos).

La imaginación es un vuelo que nunca se aleja del todo de la experiencia. «Cada uno de nosotros tiene un arco de sensibilidad más allá del cual nada existe», decía Wallace Stevens en Adagia, y esa sensibilidad está dada en buena medida por la capacidad de dejarse atravesar por lo vivido... Wallace Stevens dijo también que «lo real sólo es la base. Pero es la base». Yo creo eso. 
Andruetto, María Teresa

«¿Qué escriben y cómo escriben las mujeres?». El hilo

de la fábula. Revista anual del Centro de Estudios

Comparados (19), 171-174

Fecha de recepción: $10 \cdot 05 \cdot 19$

Fecha de aceptación: $20 \cdot 05 \cdot 19$ 